\title{
5 "The show is as intelligent as its audience": The reception of Piazza virtuale
}

Piazza virtuale was not a ratings hit, but it had a sizeable audience, which was not a given for a niche programme on a cable-only channel. The programmes were usually seen by 10,000 viewers in the first month of the programme, according to data from the Gesellschaft für Konsumforschung (GfK), which was between 0.6 and 1 per cent of the total audience, depending on the day. ${ }^{1}$

These numbers are not an indicator of the success or popularity of the show due to the survey procedure. But they do show that Piazza virtuale was not a flop despite its style, contradicting all viewing habits. This chapter is about the reception of the show, which includes not only the ratings and statistics on the number of callers, but also the reactions of the press and the audience. While press coverage is rich and well recorded (3sat's press office published a collection of all press reports in March 1993, which included more than 150 articles from the German and international press ${ }^{2}$ ), the reaction of individual viewers who were not professional journalists is more difficult to assess in retrospect. Conclusions can be drawn here from a survey conducted by the Kassel local newspaper HNA, but also from the comments published in the social medium of the time: the Usenet discussion groups, which will be addressed in the conclusion of this book.

1 The surviving ratings are available on the website of our research project: http:// vangoghtv.hs-mainz.de/wp-content/uploads/2021/04/quoten-piazza-virtuale.pdf

2 http://vangoghtv.hs-mainz.de/wp-content/uploads/2021/o2/Presse_Van-Cogh.pdf 


\subsection{Ratings and caller statistics}

According to the final press documentation, the Gesellschaft für Konsumforschung (GfK) measured an average of between 10,000 and 30,000 viewers daily for Piazza virtuale on 3sat in Germany, and between 20,000 and 60,000 viewers for reception via satellite and in Austria and Switzerland.

Such ratings were normal for 3sat's morning shows; the broadcast of the literature award Ingeborg Bachmann Preis, the ORF noon news show or the 3sat financial news also had comparable ratings, while GfK recorded no measurable audience figures at all for other 3 sat shows at this time. In the evening, however, feature films or reruns of popular programmes such as the game show Dalli Dalli, soap opera Diese Drombusch or police drama Der Alte had market shares of up to 10 per cent or audience figures of up to a million. Detailed ratings information is only available for the first month of Piazza virtuale, so it is not possible to clarify whether the ratings rose or fell during the 100-day broadcasting period.

The possibility of calling Piazza virtuale was apparently in great demand. Viewers from that time remember that it was possible to dial the show's number non-stop during the entire broadcast without ever getting through.

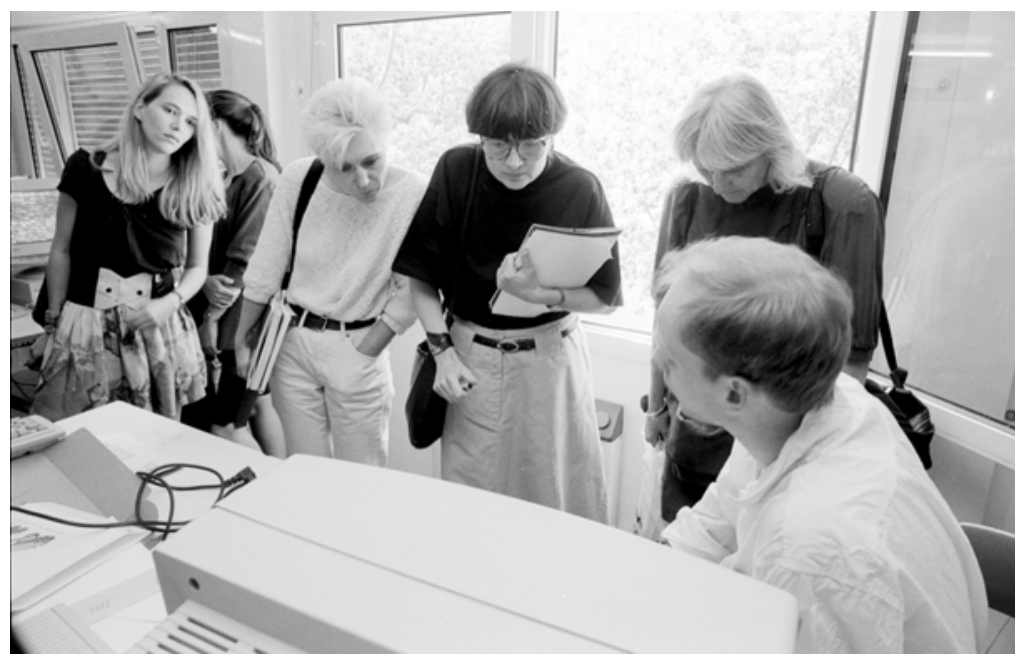

Reporters at the press preview at documenta Photo: altschaffel.com 
According to the recollection of some Piazza virtuale staffers, the number of callers once even overloaded Kassel's telephone network. ${ }^{3}$

A report for the sponsor Telekom from i September 1992 contains some interesting figures about the callers:

According to measurements by the telecommunications office in Kassel, which has a new ISDN exchange, over 110,000 calls are made per hour ... The figures allow us to estimate that 10 to 20 per cent of the viewers actually try to participate actively in the programme. After 80 days of broadcasting, 105,000 viewers have dialled into the programme and actively participated in programmes. Due to the high number of participants, released lines are immediately occupied, generating the expected telephone fee units for Telekom. ${ }^{4}$

The commitment as a sponsor had thus paid off handsomely for Telekom - which had provided no financial support but only technical services and equipment. As the report points out: "A further stimulation of telephone traffic results from the fact that telephone numbers shared via Piazza virtuale encourage viewers to communicate with each other. According to our tests, for example, between 10 and 50 responses come to a displayed fax number."

\subsection{Press reports before Piazza virtuale}

The intensive work of the press team of Piazza virtuale paid off: Piazza virtuale was covered by most of the main newspapers and magazines. In Spiegel, Piazza virtuale was honoured in advance with a two-page article by Claudius Seidl. ${ }^{6}$ In addition to a detailed background text in its TV supplement sternTV, ${ }^{7}$ Stern awarded a "Star of the Week" to Karel Dudesek. ${ }^{8}$ Bild" and Süd-

\footnotetext{
3 Interview with Christian Wolff, 22 May 2018.

4 Interim report to the sponsor Telekom, 1 September 1992.

5 Interim report, Telekom.

6 Seidl, Claudius, “Die imaginäre Pizza”, Der Spiegel, 18 May 1992, pp. 268-269f.

7 StarTV 24, 1992.

8 Star 35, 1992.

9 “100 Tage TV der Zukunft", Bild, 18 May 1992, p. 19.
} 
deutsche Zeitung ${ }^{10}$ reported on the project, and so did the city magazines, such as Prinz ${ }^{11}$ or Tip, ${ }^{12}$ that were important at the time. The spectrum of magazines interested in Piazza virtuale ranged from lifestyle and music magazines such as Tempo ${ }^{13}$ and Spex ${ }^{14}$ to art magazines like Artis $^{15}$ and even architecture magazine Baumeister, ${ }^{16}$ from computer magazines such as Mac News ${ }^{17}$ and PC Praxis $^{18}$ to industry rags like EPD Kirche und Rundfunk ${ }^{19}$ or Telekom-Monitor. ${ }^{20}$ Even Keys, a trade journal for keyboard players, found a reason to write about Piazza virtuale. ${ }^{21}$ On television, MTV and Premiere, among others, reported on Piazza virtuale.

In cities where Piazzettas existed, the local press often also wrote about the local mini-studio. The taz in Bremen, for example, reported three times on the Piazzetta in the city ${ }^{22}$ - in addition to an article in the national edition - although it was only on the air five times. Other articles about the Bremen Piazza telematica appeared in the daily Weserkurier, the city magazines Bremer, Weserreport and Prinz Bremen, ${ }^{23}$ and the local news programme Buten un Bin$n e n$ of Radio Bremen also sent a reporter to the improvised Piazzetta studio at Bremen University of the Arts.

10 'Neue Trends, neue Themen, neue Ismen, 'documenta' - total: die Kunstausstellung im Fernsehprogramm", Süddeutsche Zeitung, 13/14 June 1992.

11 Broch-Madsen, Marion, "Kunst im Kanal”, Prinz Hamburg, June 1992.

12 Liebherr, Christoph, "Kaffeehaus Van Cogh", Tip 17, 1992.

13 Renner, Karl-Hinrich, “Digitale Demokratie”, Tempo, 6 June 1992.

14 Hermes, Manfred, "Leih mir dein Ohr, leih mir dein Auge, Vincent", Spex 9, 1992.

15 Ohrt, Roberto, "Van Gogh TV", Artis, June 1992.

16 Seyfarth, Ludwig, "Die Architektur der Piazza Virtuale", Baumeister 9, 1992.

17 "Binärer Bilderofen", Mac News 9, 1992.

18 "Haf: Fernsehen zum Mitmachen", PC Praxis 9, 1992.

19 "Techno-Dumdum. 'Piazza Virtuale' auf 3sat: 100 Tage Langeweile", EPD Church and Radio no. 49, 24 June 1992.

20 "Fernsehen zum Selbermachen", Telekom-Monitor 8, 1992.

21 "MultiMedia-Spektakel zur Documenta 9", Keys 4, July/August 1992.

22 "UrDrü: Celegenheit sehr, Anlaß weniger", die tageszeitung/Bremen, 10 August 1992; Hippen, Wilfried, "Bremen so blaß wie Riga spannend", die tageszeitung/Bremen, 24 August 1992; Hippen, Wilfried, “Die Ferngesehenen: Jeder darf mal ins TV”, die tageszeitung/Bremen, 13 July 1992.

23 "Ther: Bremen weltweit auf Sendung", Kurier am Sonntag, 23 August 1992; Heldt, Ina, "Piazza Virtuale live auf 3sat", Bremer 8, 1992; "fc: Per Bild-Telefon dabei sein", Weser-Report 8, 1992; Fischer, Frauke, "Bremen grüßt Kassel”, Prinz Bremen, 8, 1992. 
The advance coverage of Piazza virtuale was largely factual, often sympathetic and positive. What is striking is the willingness of the media to report without seeing a preview of the planned show and only on the basis of the information provided by the makers - after all, what would actually be on television only emerged when the show was broadcast. Some of the authors were apparently so convinced of the concept that they opened up a theoretical-aesthetic framework for the project without any basis in their own experience. Apparently, both the relevance of the content and the sheer technical feasibility seemed so self-evident that the writers wanted to formulate their own thoughts about a show that did not yet exist and would only emerge from the participation of the audience.

Particularly interesting here are the articles published by Claudius Seidl in Spiegel and Klaus Bartels in Page. Bartels was able to persuade a professor of German literature from Hamburg University who was interested in media theory and digital media to contribute to the design magazine Page. His text offers a good overview of the topics and approaches that were under discussion at the beginning of the 1990 and mentions authors such as Marvin Minsky and Hans Moravec, Peter Weibel and William Gibson, Brenda Laurel and Timothy Leary, Bertolt Brecht and Hans Magnus Enzensberger. ${ }^{24}$

Among the buzzwords in his text are terms omnipresent at the time, such as virtual reality and cyberspace, telepresence and hypertext, convergence and interactivity. The text is in part a time capsule of the debate of the time about an imminent media future, in which media theorists and propagandists outdid themselves in describing and embellishing this future with elegant metaphors or by invoking historical references. ${ }^{25}$

Claudius Seidl, who published a two-page article about the project in Der Spiegel barely a month before Piazza virtuale went on air, also had to write his announcement on the show based on what its makers told him beforehand. That didn't stop him from declaring Piazza virtuale to be part of a great upheaval in television culture: "The audience breaks the power of the broadcasters, the viewers make their own programmes, the screen becomes accessible for everyone who has something to say." ${ }^{26}$ After a reference to Brecht's

\footnotetext{
24 Bartels, Klaus, “Virtueller Honig”, Page 6, 1992, pp. 4-11.

25 The anthology edited by Manfred Waffender - Cyberspace: Ausflüge in virtuelle Wirklichkeiten, Hamburg: Rowohlt, 1991 - is a representative overview of such texts.

26 Seidl, "Die imaginäre Pizza”, Der Spiegel, p. 268.
} 
radio theory, Seidl describes how in Piazza virtuale "television is to become a setting for strolling, chatting, acting, easily accessible and as cheerful as the marketplace of an Italian town". ${ }^{27}$ Ultimately he comes to the conclusion: "Piazza virtuale prepares the deconstruction of television, it mocks the laws of the medium, just as deconstructivist architecture mocks the laws of gravity - and for that reason alone it is a work of art at the height of our postmodern times."28

\subsection{The press coverage during Piazza virtuale}

How did the press react to a TV programme that was loftily announced as "a kind of electronic pedestrian zone for street hawkers, virtual bums, onlookers, preachers, street painters, shoppers, tourists and musicians", ${ }^{29}$ but soon after its launch was nicknamed "Hello TV"? Interestingly, the positive reactions came mainly from technically oriented media. The magazine $P C$ Professional, for example, in a special issue on the subject of "Multimedia", found that the show "was still in the absolute early stages, but shows the direction in which multimedia can and will change everyday life in the near future". ${ }^{30}$ And the industry publication Telekom Monitor said: "All the completely new and unfamiliar impressions that flickered across the screen ... and that at times were also creepily distorted or did not yet function in a completely coherent manner, were in their entirety more exciting than many an American series." ${ }^{\text {1 }}$

Possibly because the writers were able to assess the technical complexity of Pizza virtuale or because they simply had high hopes for the "interactive future" of television, the show's weak points were excused in technically oriented magazines because of its potential. The trade journal Professional Produktion wrote:

\footnotetext{
27 Ibid.

28 Ibid.

29 Müller, "Kabel, Chaos und Kultur", MacUp, p. 5.

30 PC Professional Extra Multimedia, 1992.

31 Telekom Monitor 8, 1992.
} 


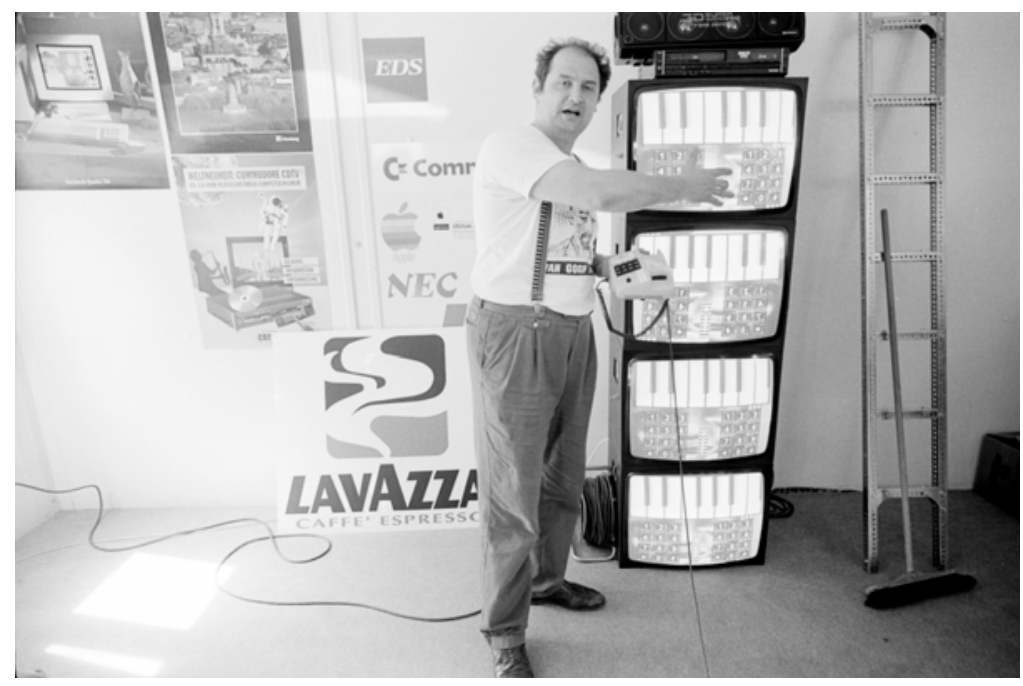

Karel Dudesek talks about Piazza virtuale at the press conference. In the background the logos of some of the sponsors of the show Photo: altschaffel.com

The idea is good and important, but in its present form interactive television is still a toy for computer freaks and self-promoters. Those who have managed to get in only produce redundancy. Communication as a meaningful exchange of information, which can be important and informative but also just entertaining, does not take place here. The complete rejection of the sender/ receiver constellation of television, and thus the rejection of playing prepared contributions, place Piazza virtuale in the corner of artistic experiments. Nevertheless, these experiments will go down in media history. ${ }^{32}$

But the unusual programme was of course also met with rejection in some quarters. The newspaper Neue Westfälische found it "simply boring and stupid". ${ }^{33}$ Süddeutsche commented:

Simple minds, who articulate themselves electronically like graffiti artists, are of course also part of the show. And when someone bursts in quite unsuspec-

32 Singer, Harald, "Elektronische Kunst auf der documenta 9", Professional Produktion, 8, 1992. 33 “Lili: Dresden grüßt Köln”, Neue Westfälische, 16 June 1992. 
tingly, he has this to say from Seligenstadt: "What's the show about?" No answer, just a request from the off to speak English. What's it all about is probably also asked by the silent majority of those who don't pick up the phone, but merely press the button on the remote control to find the next game show. ${ }^{34}$

Die Welt observed: "It becomes clear that the most important motivation for taking part is self-expression, or to hear one's voice on TV when it says naughty things." ${ }^{35}$ Hamburger Rundschau summed it up succinctly: "The programme is as intelligent as its audience."36

In some reviews, Piazza virtuale was accused of being overly fixated on technology. "Enormous logistics for a harmless playground!" was the verdict of the Berlin city magazine zitty, which included a list of all the sponsors mentioned in the programme's credits, which took up almost an entire column. "The media games are voluntary laboratory experiments to increase the efficiency of industrial media technology", wrote Tagesspiegel. ${ }^{38} \mathrm{NZZ}$ shared this perspective: "Most of it is predetermined by an invisible 'machine'; accordingly, the individual feels like a rat in a rigid experimental facility that is not transparent to them. ${ }^{39}$ And the music magazine Spex agreed: "In a happy, because powerful, position are those who sit in the Van Gogh TV container and can fiddle around with the many marvellous, sponsored devices ... Ultimately it will be service providers like the sex industry that can do something practical based on this research. ${ }^{20}$

Some reviews emphasise the failure of the media utopia that wanted to turn consumers into producers: "It turned out, however, that the viewers, who had advanced to become participants, often didn't know what to do with their newly won freedom. The medium was too new, and there were fears of contact that sometimes led to speechlessness or real nonsense." ${ }^{\text {n1 }}$

34 Pardey, Hans-Heinrich, "Verlorene Hallorufe auf der virtuellen Piazza", Süddeutsche 14 July 1992.

35 Schwerin, Christoph, "Interaktives Fernsehen", Welt, 19 June 1992.

36 Anonymous, "Flimmerkiste für Sesselschläfer", Hamburger Rundschau, no date.

37 "Teo: Piazza Virtuale. Fernseh-Computer-Telefon-Spielplatz", zitty 17, 1992.

38 Vogel, Sabine, "Kommunikationsfluss in die andere Richtung", Tagesspiegel 16 August 1992.

39 "Ras: Rückblick auf Sendungen der Woche. 'Piazza Virtuale'? Blabla reale”, Neue Zürcher Zeitung, 28/29 June 1992.

40 Hermes, "Leih mir dein Ohr, leih mir dein Auge".

41 Krajewski, Peter, "Im Chaos aber blüht der Ceist", pablo, no date. 


\subsection{The audience survey}

The reaction of the public is far less easy to document than published opinion. That is why the survey that the Kassel local newspaper Hessische/Niedersächsische Allgemeine (HNA) conducted among its readers in August is so interesting. With the help of a competition, the public's opinion of the programme was to be determined - this in itself was an indication that Piazza virtuale was noticed and discussed in Kassel and at documenta. The editors' summary: "The response was extremely divided, but the majority was positive. Incidentally, many readers complained that they had tried several times to participate in the show but never got through." From the positive submissions, the article quotes the following voices: "Short and simple: Your programme is great. We will miss you very much!' - 'My fingers itched every time to pick up the phone to be there live.' 'I've spent many a night tossing and turning just to see this wacky programme. ${ }^{\text {.42 }}$

But of course there was criticism, too:

People often complained about the confusion on the screen, several readers wrote that at first they thought there was a malfunction. Others accused the makers of not having provided enough information about the show and the opportunities to participate in advance. One summarised it as follows: "Idea good, execution messy, result incomprehensible." ... Criticism was also levelled at unimaginative participants: "If you don't know how to say more than 'hello', you shouldn't make that known to the public", said one young woman.

Other letters expressed the hope that sponsors would be found to continue Piazza virtuale after the end of documenta.

42 These and the following quotations from "Hpo: Praise and Blame for Participatory TV", 30 August 1992. 


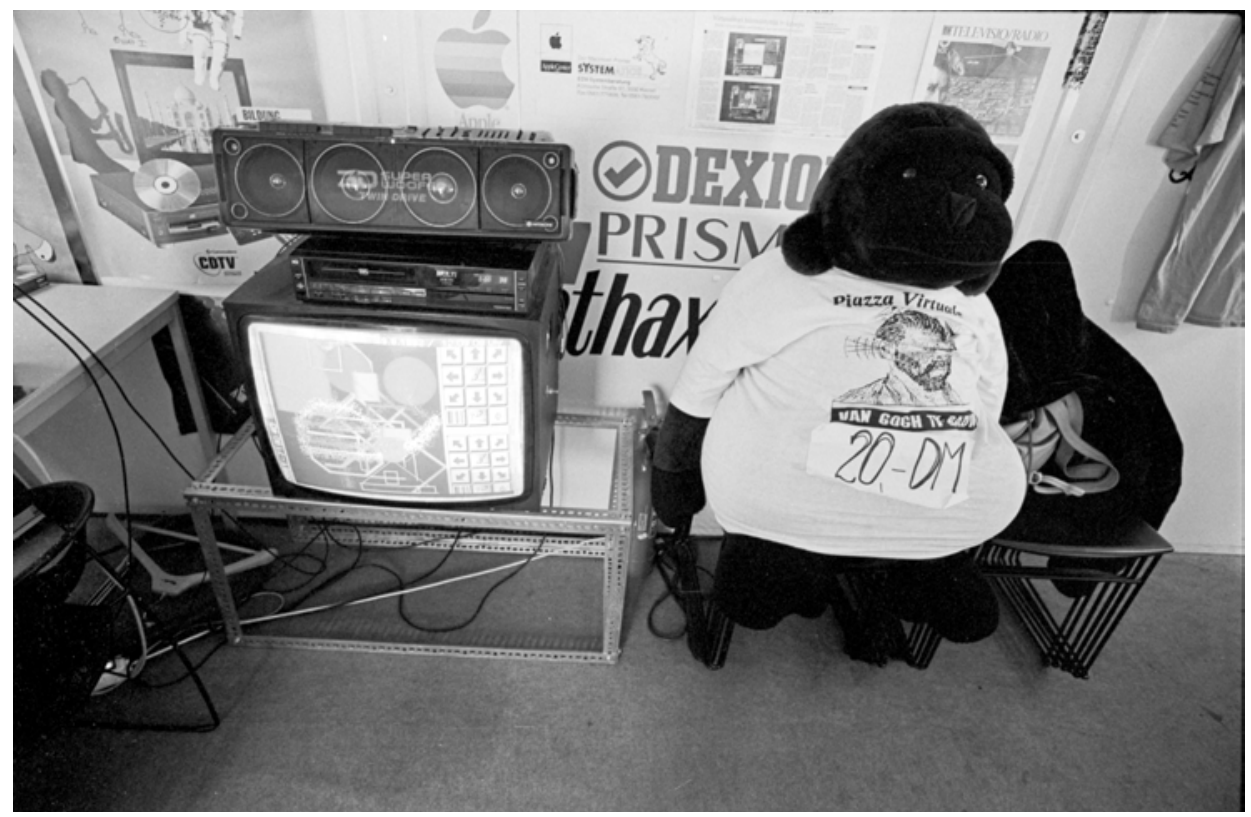

Inside the container studio of Piazza virtuale

Photo: altschaffel.com 